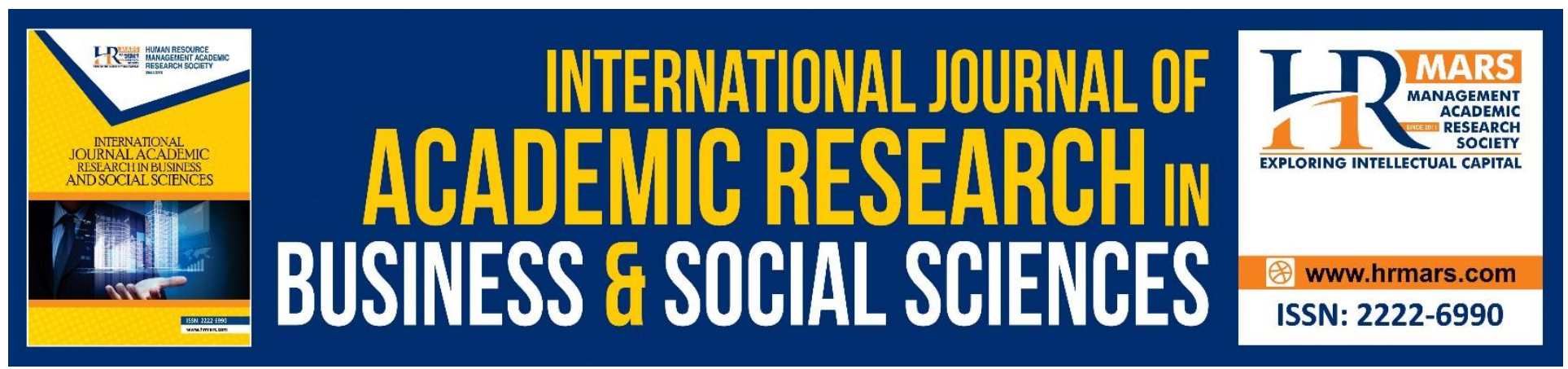

\title{
Study on the Forgiveness Concept of Aceh Conflict Victims
}

\author{
Hafnidar, Nursan Junita, Ratna
}

To Link this Article: http://dx.doi.org/10.6007/IJARBSS/v8-i8/4943

DOI: $\quad 10.6007 /$ IJARBSS/v8-i8/4943

Received: 14 July 2018, Revised: 07 August 2018, Accepted: 30 August 2018

Published Online: 08 Nov 2018

In-Text Citation: (Hafnidar, Junita, \& Ratna, 2018)

To Cite this Article: Hafnidar, Junita, N., \& Ratna. (2018). Study on the Forgiveness Concept of Aceh Conflict Victims. International Journal of Academic Research in Business and Social Sciences, 8(8), 835-850.

Copyright: (C) 2018 The Author(s)

Published by Human Resource Management Academic Research Society (www.hrmars.com)

This article is published under the Creative Commons Attribution (CC BY 4.0) license. Anyone may reproduce, distribute, translate and create derivative works of this article (for both commercial and non-commercial purposes), subject to full attribution to the original publication and authors. The full terms of this license may be seen at: http://creativecommons.org/licences/by/4.0/legalcode

Vol. 8, No. 8, August 2018, Pg. 835 - 850

http://hrmars.com/index.php/pages/detail/IJARBSS

JOURNAL HOMEPAGE

Full Terms \& Conditions of access and use can be found at http://hrmars.com/index.php/pages/detail/publication-ethics 


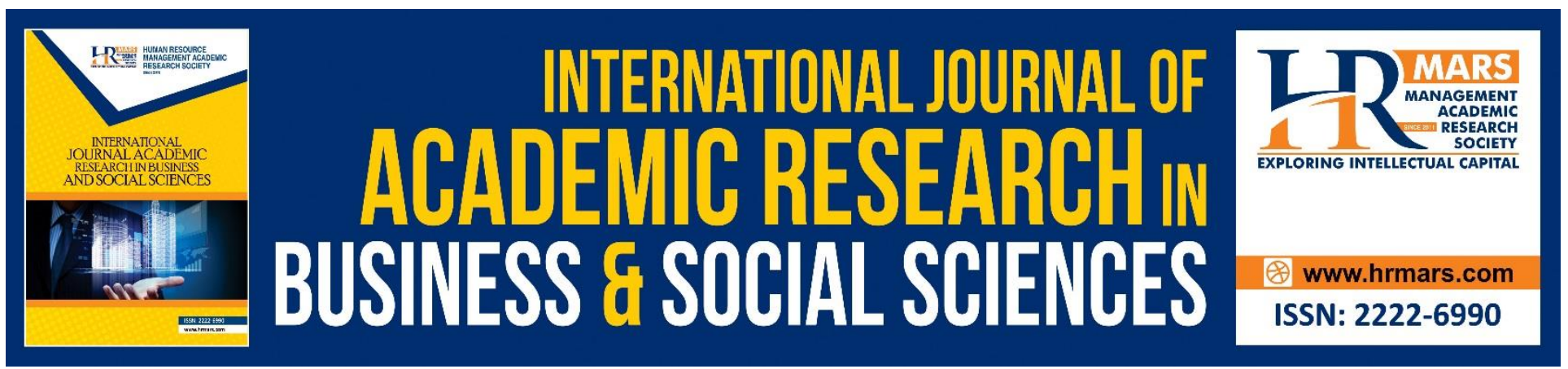

\title{
Study on the Forgiveness Concept of Aceh Conflict Victims
}

\author{
Hafnidar \\ Department of Psychology, Malikussaleh University, Lhokseumawe-Aceh, Indonesia \\ Nursan Junita \\ Department of Psychology, Malikussaleh University, Lhokseumawe-Aceh, Indonesia
}

\begin{abstract}
Ratna
Department of Economic Development, Malikussaleh University, Lhokseumawe-Aceh, Indonesia
\end{abstract}

\begin{abstract}
Acehnese people experience traumatic experiences due to conflict and prolonged war in Aceh. This research was conducted by using phenomenology as a qualitative method. The aims of research are to find the forgiveness basic concept of Aceh people. The total of research participants were 10 respondents which chosen from Aceh conflict victims by using purposive sampling technique. The data collection methods utilized in-depth interviews, observation, and analysis of documentation. This study applied the important principles in a phenomenology research: epoch, phenomenological reduction, imaginative variation, and synthesis of meanings and essences. The concept of forgiveness varies depending on the socio-cultural norms of each individual. The results reveal that for the Acehnese who are rooted in the conceptualized culture of Islam, the concept of forgiveness is closely related to the concept of spirituality, post traumatic growth (PTG), coping strategic and positive selfconcept.
\end{abstract}

Keywords: Forgiveness, Concept, Aceh, Conflict Victims

\section{Introduction}

Conflict and war in Aceh took place for a long time, since colonial time until after the independence of the Republic of Indonesia. The conflict between the Indonesia Government and the Free Aceh Movement (GAM) took place from 1976 to 2005. Nurrachman (2005) said that on an individual level, the tragedy of Aceh conflict can leave physical, mental and emotional trauma, and from the social level, the events will always be remembered and memories will be passed on from generation to generation. This memory may not be separated from hatred and resentment.

After a long period of conflict and warfare, on August 15, 2005, the Government of the Republic of Indonesia and the Free Aceh Movement (GAM) officially signed the memorandum of understanding 
INTERNATIONAL JOURNAL OF ACADEMIC RESEARCH IN BUSINESS AND SOCIAL SCIENCES Vol. 8, No. 8, August 2018, E-ISSN: 2222-6990 @ 2018 HRMARS

(MOU) on peace treaty. It was the third peace agreement. The previous two peace treaties that have been signed by both sides have failed. Therefore peace in Aceh still needs continuous care, forgiveness is one way for lasting peace. Warmke \& Warmke (2016) says that forgiveness allows both sides to look at painful past in different ways. Enright \& Coyle (1998) define forgiveness as processes towards a transgressor are replaced with positive thoughts, feelings, and behaviors. Yan-Gen et al. (2017) view forgiveness can help repair interpersonal relationships, promote pro-social motives, enhance social skills, and bring positive psychological, emotional, and social results.

According to Enright \& North (1998), Rye et al. (2000), the concept of forgiveness is varies depending on the socio-cultural norms of each individual, which affects the way a person thinks, feels and behaves. Likewise, the Acehnese who are rooted in the conceptualized culture of Islam, need to learn to find the basic concept of forgiving and the concept of forgiveness in accordance with the culture of the Acehnese society that is a Muslim majority.

Beside, several experts mention that forgiveness has a positive relationship with a number of psychological aspects in human beings such as well-being, self-esteem, depression, anxiety, spirituality, and post-traumatic development (Enright \& Fitzgibbons, 2000 ; Fischer, 2006; Fincham, 2015; Lutjen, Silton, \& Flannelly, 2012; Maltby, Day, \& Barber, 2004), Matter, Mcfarland, Smith, Toussaint, \& Thomas Smith, Toussaint, \&Thomas,2012; Svalina \& Webb, 2012; Unterrainer, Lewis, \&Fink, 2012; Webb 2012; Unterrainer, Lewis, \& Fink,2012; Webb, Phillips, Bumgarner, \& ConwayWilliams 2012).

\section{Method}

This research uses qualitative phenomenological approach to find the concept of forgiveness in Acehnese society. A total of 10 respondents were selected using purposive sampling technique, that is based on the following predetermined criteria: (1) is one of the following elements: Islamic leaders, scholars, casualty in remote areas and urban area, social activists, political organization activist, government official, housewife, as well as representatives of each profession in society, (2) Represents direct victims of Aceh conflict, (3) A native Acehnese and have lived in Aceh since the conflict until now. The data collection methods used in-depth interviews, observation and documentation analysis. 
INTERNATIONAL JOURNAL OF ACADEMIC RESEARCH IN BUSINESS AND SOCIAL SCIENCES Vol. 8, No. 8, August 2018, E-ISSN: 2222-6990 @ 2018 HRMARS

Table 1. General Profile of Participants

\begin{tabular}{|c|c|c|c|l|}
\hline No & $\begin{array}{c}\text { Pseudo Initial } \\
\text { Name }\end{array}$ & Age & Gender & \multicolumn{1}{|c|}{ Information } \\
\hline 1 & AS & 65 & M & Islamic leaders \\
\hline 2 & DN & 44 & M & Scholars \\
\hline 3 & AZ & 51 & M & Victims in remote area \\
\hline 4 & AM & 54 & F & Victims in urban area \\
\hline 5 & MY & 40 & M & Social activist \\
\hline 6 & SY & 45 & M & Political organization member \\
\hline 7 & MN & 55 & M & Government official \\
\hline 8 & TM & 38 & M & Ex Combatant \\
\hline 9 & HR & 40 & F & Ex Combatant \\
\hline 10 & PP & 32 & F & Housewife \\
\hline
\end{tabular}

According to Moustakas (1994), there are several important processes in phenomenology research: epoche, reduction, imaginative variation, and synthesis of meanings and essences. Epoche is the process of eliminating prejudices, reducing biases and opinions on things. Reduction is a methodical procedure whereby the researcher can interpret knowledge from fact to idea or from fact to essence in general. Then, in the process of imaginative variation, researchers look for possible meanings through the use of imagination, differentiation of various reference frames, grouping and reversal, and phenomenon approach from diverging perspectives, positions, roles, or different functions. The goal is to achieve a structural description of experience, the underlying factors and affect what has been experienced.

The steps in conducting imaginative variation included: (1) Establish systematically from the possibilities of all constructed meanings that may be the basis of the textural meaning, (2) Recognize themes or contexts as the basis for the cause of the phenomenon, (3) Consider the overall structure that can lead to conclusions that are too fast for the feelings and thoughts associated with a phenomenon, such as the structure of time, space, attention that is only focused on the main things, materiality, causality, relationships with self, or relationships with other people, (3) Look for illustrations as examples that can give a clear picture of the structure of unchanged themes and facilitate the development of structural phenomenon description. The final step of the phenomenological research process is the fundamental integration of the textural and structural descriptions into a statement as the essence of an experience of the overall phenomenon (Moustakas, 1994).

\section{Research Finding}

Most of the Acehnese are Muslims. The perseverance and conviction of the people of Aceh in religion is very high. Umar (2002), Alfian (1999), Alfian et al. (1997) said that the Acehnese will not hesitate to label kafhe (infidel) to tribes or nations that are hostile to Islam. The word kafhe is used to remind Muslims to be careful of people who want to infiltrate any belief that is contrary to the teachings of Islam. Agama Islam has become part of the pride and dignity of Acehnese that should not get interference from anyone. As Muslims, Acehnese are basically forgiving, but the Acehnese have a principle of maintaining religious beliefs as implied in the following saying: 
INTERNATIONAL JOURNAL OF ACADEMIC RESEARCH IN BUSINESS AND SOCIAL SCIENCES

Vol. 8, No. 8, August 2018, E-ISSN: 2222-6990 @ 2018 HRMARS

Sihèt bek, rō beu habèh

Meaning:

Lean not, spill all

Umar (2002), Alfian (1999), Alfian et al. (1997) said that philosophy greatly influenced the life of the people of Aceh when the Portuguese and the Dutch began to interfere religious life, pride and dignity of Acehnese. In the beginning, Portuguese and Dutch came to Aceh as merchants. As an open and friendly nation, the people of Aceh treated the Portuguese and the Dutch well. But behind the openness and generous attitude, there is one restriction in interacting with the Acehnese as revealed in the following pantun:

Ureueng Aceh meunyoe hate hana teupèh

Aneuk krèh jeut taraba

Meunyo hate ka teupèh

Bu leubèh han in peutaba

Meaning:

If his heart of an Acehnese is not offended

The vital organ can be touched

If his heart is hurt

No rice is offered, even when excessive

The Pantun above implies that not being offensive is the main requirement to interact with Acehnese. The heart or feeling is closely related to pride and dignity, in this case is the religious beliefs and life of the people of Aceh. Umar (2002), Alfian (1999), Alfian et al. (1997) said that the Dutch and Portuguese were initially well received by the Acehnese, but over time the Acehnese considered that the Dutch had offended the Acehnese by harassing the religion and life of the Acehnese, so the Acehnese agreed to fight against the Dutch. The Portuguese and the Dutch did not accept the principles of the Acehnese not to interfere with their life and religion. The consequences of the principle resulted in misunderstandings, debates, quarrels, and then war for 120 years (1515-1636). Snock Hurgronje, who played the key role in this matter, tried to divert the teachings of Islam with the target of Muslims in Aceh by attempting them into confrontations with one another so it's easy for the Dutch to conquer them. Therefore the will of expelling the Portuguese and Dutch occupation was stronger, as read in the rhyme: 
INTERNATIONAL JOURNAL OF ACADEMIC RESEARCH IN BUSINESS AND SOCIAL SCIENCES

Vol. 8, No. 8, August 2018, E-ISSN: 2222-6990 @ 2018 HRMARS

Kuala Bak U timō rangkilèh

Kuala Sibadèh timōh bak Bangka

Aceh nyang karu pane na puleh

Yōh tan ta peuwèh kaphè Beulanda

Meaning:

Kuala Coconut trees grow Rangkileh trees

Kuala Sibadeh grow Mangroves

The chaotic Aceh will not be safe

Until the Dutch infidel is expelled

According to Umar (2002), Alfian (1999), Alfian et al. (1997), the first conflict occurred in Aceh after the independence of the Republic of Indonesia also because of the religious beliefs, self-esteem and dignity of the Acehnese. Teungku Muhammad Daud Beureueh as the Acehnese leader of that time fully supported the independence of the Republic of Indonesia. Teungku Muhammad Daud Beureueh agreed that Aceh, which never surrendered to the colonists, would be a part of Republic of Indonesia so that Indonesia can proclaim its independence. However, Teungku Muhammad Daud Beureueh was disappointed with the Indonesian Government that did not keep its promise. Teungku Muhammad Daud Beureueh was forced to protest to the central Indonesian government through DI / TII party that he created.

According to Hardi (in Umar, 2002), the cause of the creation of DI / TII which is followed by the declaration of the starting point of Aceh Merdeka (Aceh movement) by Hasan di Tiro in 1976 is that the central Indonesian government paid too little attention to the interests of the Acehnese, that the central government obstructed the implementation of Islamic teachings in Aceh to provide wide autonomy to Aceh. The central government also dissolved Aceh to be unified with the Province of North Sumatra. The philosophy of sihet bek, rō beu habèh: tilt not, spill all, is already ingrained in the people of Aceh. Therefore, when religious life, the pride and dignity of Acehnese people cannot be restored, the conflict and war in Aceh will continue to occur. After the declaration of Aceh Merdeka, the conflict and war in Aceh occurred for almost 30 years. The conflict and the war ended after the devastating earthquake and tsunami in Aceh on December 26, 2004.

\section{Definition of Forgiveness}

The participants of this study reported that determination is an important variable in the process of forgiveness. In other words, forgiveness is achieved if all parties start with willingness to do so. Willfulness comes from hearts and minds who want a happy life in the world and after life. This study found the definition of forgiveness is the willingness and ability to control negative thoughts, feelings and behaviors about bad experiences into positive thoughts, feelings and behaviors whether it is forgiving oneself, situations, and others. Aceh conflict victim's willingness very important in this study, because willingness may increases Aceh conflict victim's ability to control thoughts, feelings and negative behavior that influenced by emotional intelligence, self-concept, coping strategy, post traumatic growth, and spirituality which explains in chart 1. 


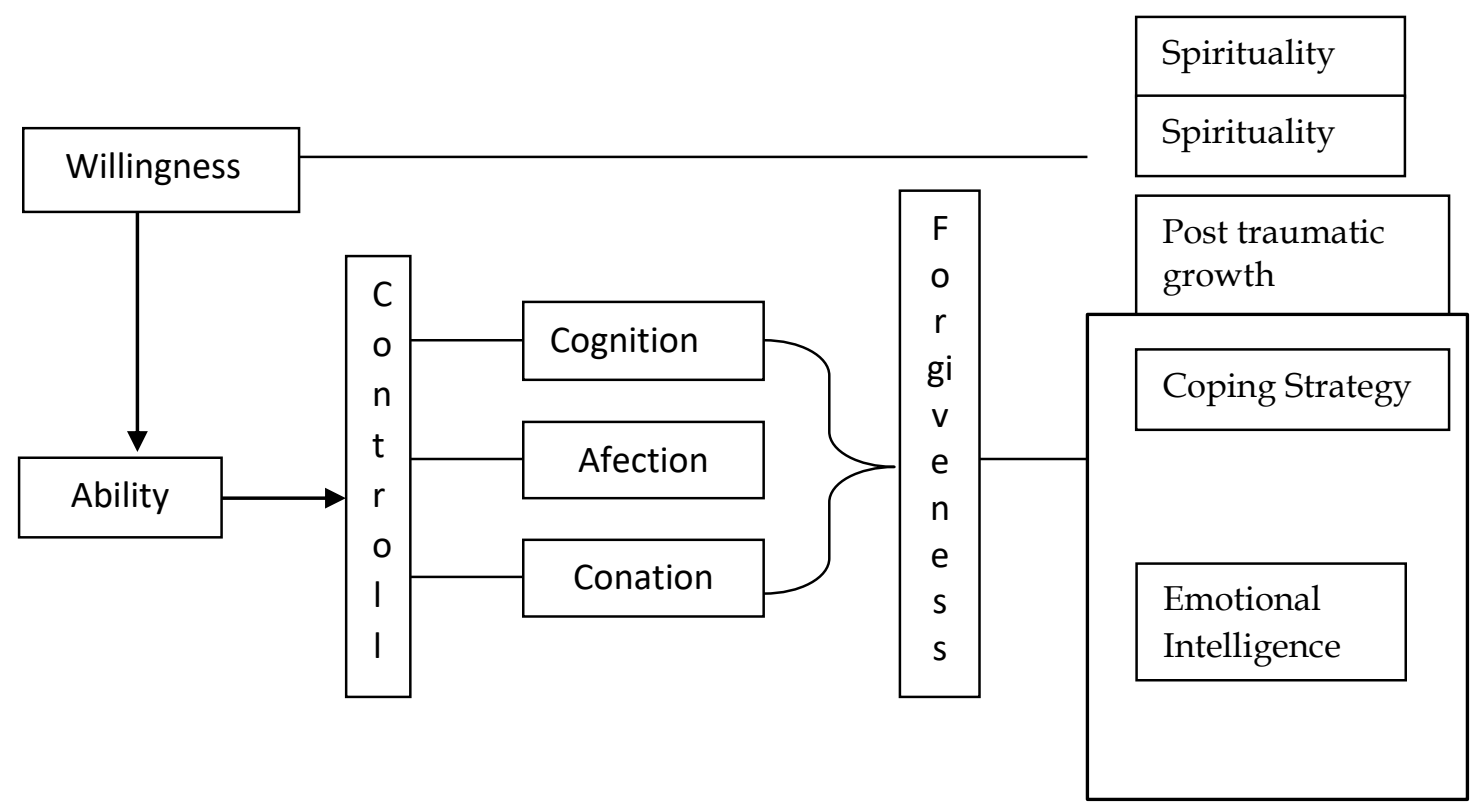

Figure 1. Diagrams the forgiveness process of Aceh conflict victims

Several factors that influenced the Aceh conflict victims willingness to forgive are showed in Figure 1 , that's spirituality, post traumatic growth, religious coping strategy, self-concept, and emotional intelligence.

Acehnese community as people who hold strong Islamic values, actually it is not so difficult for leaders to awaken the will to forgive. But now Aceh has lost charismatic leaders. Many current leaders have no place in the hearts of Acehnese. The Acehnese have philosophy on the importance of wise leaders as the below pantun:

Sikrèk sikato

Dua krèk bungoh uroe

Meaning:

One piece of one word

Two pieces in the morning

The pantun has a symbolic meaning that the wise leader of Aceh is not easy to just indulge in words. If the leader speaks, then his words should have a deep meaning, touching the hearts and feelings of people who hear it (Umar, 2002). The words of the Acehnese leader can make the person who hears him is unable to sleep until the morning for he will contemplate the wisdom of the leader's words. That is how the Aceh people describe the character of a wise leader of Aceh. Such leaders are easy to have followers. Sultan Iskandar Muda, Teungku Daud Beureueh, and independence heroes such as Teungku Umar, Cut Nyak Dien, Cut Mutia, etc. are charismatic figures as depicted in the pantun. Presently, the Acehnese have not yet found the ideal leader figure. Today's leaders are easy to give promises, rude, and inconsistent between deeds with words or called munafék (hypocritical). Umar (2002) said that for the Acehnese, hypocrisy is a very bad trait, sulet only has a dishonest nature while munafek has three types of traits such as said in the Hadith of Prophet Muhammad SAW. 
INTERNATIONAL JOURNAL OF ACADEMIC RESEARCH IN BUSINESS AND SOCIAL SCIENCES

Vol. 8, No. 8, August 2018, E-ISSN: 2222-6990 @ 2018 HRMARS

The crisis of confidence has been going on for so long in Aceh. The crisis of confidence in leaders has resulted in long-standing conflicts and warfare in Aceh. Therefore the Acehnese cannot tolerate an unwise leader as depicted in the following pantun:

Dari pada crah leubèh gèt bèukah

Dari pada sihèt rho bah habèh

Pakri ban crah lagée nyan beukah

Pakri ban manoe lagèe nyan basah

(Umar, 2002)

Nevertheless, the approach of spirituality has a strong influence on the willingness of the Acehnese to forgive. The approach of spirituality can even diminish the influence of philosophy: Sihet bek, rō beu habeh (tilt not, spill all) in society. The earthquake and Tsunami of Aceh on 26 December 2004 was the world's greatest disaster in the 21st century. In the spirituality of the disaster that devastated all aspects of Acehnese life, economic, material, social, law, education, health. Umar (2002) said that most Acehnese interpreted The earthquake and Tsunami of Aceh as a reprimand from Allah Subhanallahutaala to stop the bloodshed in Aceh. The disaster leaves a deep traumatic experience, for people who experience it directly or indirectly.

The earthquake and Tsunami of Aceh is so imprinted in the souls of the people of Aceh until now. In line, according to participants of this study, said that the key to maintaining peace in Aceh is to encourage and give Acehnese the opportunity to improve their spirituality in all aspects of their lives, including economic, legal, socio-cultural, health and education. Increasing the spirituality of the Acehnese is to restore the Acehnese to its own culture and customs.

Bèk talèt gajah ka u gle

Bek tiek kawee dalam ie tuba

Bek top galah bak tanoh cayé

Bak kayè mate bék tatak tanda

Meaning:

Do not chase elephants that have entered the forest

Do not fish in poisoned water

Do not stake poles in liquid soil

On the dead wood do not make a mark

That Pantun was created by parents in the past in an attempt to find a way out for every problem in Aceh. The first line of the pantun that reads bek talet gajah ka u gle (do not chase elephants that have entered the forest) contains imagery that if the Acehnese culture and customs are disturbed then the Acehnese will react to fight for the culture and tradition of social life to be as it was. Therefore, Elephants that have entered the habitat of the forest do not be pursued again. If Aceh people have already forgiven and moved on their live according to their believe, do not disturb anymore (Umar, 2002; Syamsuddin, 1977).

If the country is chaotic, people will no longer think of ethics and rules. The citizen will be like drunken people who are intoxicated by the poison of conflict, and only think about his/her safety, as written in the second line Bek tiek kawee dalam ie tuba (do not lure the fish into poisoned water). Similarly, 
INTERNATIONAL JOURNAL OF ACADEMIC RESEARCH IN BUSINESS AND SOCIAL SCIENCES

Vol. 8, No. 8, August 2018, E-ISSN: 2222-6990 @ 2018 HRMARS

the third row of pantun Bek top galah bak tanoh caye (do not put up the pole in liquid soil), contains the imagery that the foundation for a solution of a problem must be strong so that the solution can last long to maintain peace in Aceh (Umar, 2002; Syamsuddin, 1977).

The Acehnese are very careful in trying to solve the problems that occur. First see the condition of the community before giving treatment. Because, like dead wood in which the bark and stems are already, it cannot be marked with a scratch of sharp objects which implies in last line of pantun. Therefore, to reconcile disputes and give advice, condition of the community must be examined first whether it is appropriate to receive such advice. An advice given to a community that suffers from hunger for days, never having any education at all, with chaotic life, will give different impact on a safe and prosperous community.

Spirituality approach is also appears in coping strategy of Aceh conflict victims. Aceh is the worst area hit by the earthquake up to 9.3 on the Richter scale and Tsunami waves up to $15 \mathrm{~km}$ on December 26, 2004 ago. According to data from the Indonesian Ministry of Social Affairs, the disaster claimed at least 105,262 victims in Aceh and North Sumatra. This disaster resulted in most Acehnese experiencing traumatic symptoms and post traumatic syndrome. According to Hartini (2011), most Acehnese use spirituality as coping strategy so not all victims of earthquake and tsunami experience post traumatic syndrome. Carlson (2007) defines coping strategies as a form of a person's response to the stress he is experiencing and effectively reduces the level of stress he is experiencing.

In-line Community Care of Humanity (2012) reported that almost all victims of the Earthquake and Tsunami in North Aceh District use the spirituality approach as their coping strategy. If traumatic symptoms such as fear without cause, fast heart beat, headache, sleeplessness, and others appear, then most victims of the earthquake and tsunami of Aceh claimed to perform zikr, sunnah prayer, surrendering all its problems to Allah Subhanallahutaala. By conducting a spiritual coping strategy, the traumatic symptom felt by the conflict victims in North Aceh is decreasing.

The spirit of the Acehnese in addition to allowing one to forgive, also allows one to grow in the future after a painful event or so-called post traumatic growth. this study found that who Acehnese can forgive their-self, situation and others have an optimistic character, not despairing of God's grace, not complaining and sorry for past events, being more oriented towards the future with take a lesson on past events and believe his life in the future will be better.

Beside, this study also found that the Acehnese who can forgive and have post traumatic growth are encouraged by their positive self-concept. According to Hurlock (1973), the concept of self concept is defined as the thinking, feelings and emotions of a person related to the quality and ability of himself in adjusting to life. People who have a positive self concept can view themselves positively and tend to be more successful than people has a negative self concept. Bochner (1994) said that the socio-cultural environment is one aspect that can affect the formation of self-concept in a person.

Positive self concept in Acehnese is highly influenced by Aceh culture. Umar (2002) mentions that Acehnese really have embedded the attitude of confidence and belief on the quality of the principle. This character is obtained by blood, religion, customs and culture, as well as educational background. The Acehnese customs and culture are based on strong Islamic principles. Aceh people throughout the ages are still remembered by the past glory of Aceh in applying Islamic values as custom and culture. The power of the Aceh Darussalam Kingdom under the leadership of Sultan Iskandar Muda included the Malacca peninsula. The sovereign kingdom of Aceh is well-known for its prosperity and peace for 29 years which from 1607 until 1636. After Sultan Iskandar Muda dethroned, the kingdom of Aceh Darussalam began to slow down. 
INTERNATIONAL JOURNAL OF ACADEMIC RESEARCH IN BUSINESS AND SOCIAL SCIENCES Vol. 8, No. 8, August 2018, E-ISSN: 2222-6990 @ 2018 HRMARS

Along with that came the Europeans for the expedition to find the land of colonies to Indonesia. In contrast to other regions, the fight against Portuguese, Dutch and Japanese occupation in Aceh lasted for a long time. Aceh is most famous for producing heroes. Aceh is the only region in Indonesia that is not conquered by any colonization. As a region never conquered, Aceh can support Indonesia to proclaim its independence. Aceh is willing to join the state of Indonesia on the basis of fellow Muslims are brothers. Not only that, after the independence of the Acehnese people can collect gold and silver to donate to Indonesia as the embryo of Garuda Air Lines and the establishment of the gold-plated Monument (Umar, 2002; Alfian, 1999; Alfian et al, 1999; Sawitri et al, 1999; Syamsuddin, 1977). The history of the Acehnese is formed as a custom and a growing culture that affects the formation of a positive self concept in the Acehnese. Concluded that positive self-concept in Acehnese has supported the manifestation of forgiving behavior. The historical experience, customary and cultural conditions of Aceh have established a strong sense of confidence in Acehnese, which can raise the optimism that Acehnese who have forgiven can turn a painful past experience into a glorious future.

\section{Dimensions of Forgiveness.}

The result reveals that the dimensions of forgiveness of Aceh conflict victims are forgiveness of self, forgiveness of others, and forgiveness of situations. According to Aceh conflict victims, forgiveness of self consist: (1) willingness to acept God's fate, (2) willingness to taking lessons from bad past experiences, (3) having hope for future, and (4) always be grateful. Willingness to acept God's fate defined as willing to believe that everything is a scenario that God has established for one, having no regrets about what has happened, and having a positive self-concept. Aceh conflict victims believe that God never has evil intentions for his servant. It also means simply expecting a good outcome from Allah SWT. It can also mean ridha, as said Hadith of the Prophet SAW, namely: "If Allah loves a person then He will test them. Anyone who is blessed (to the test) then for him ridho Allah and those who are angry (against the test) then for him his wrath." (Tirmidhi and Ibn Majah At Tirmidhi, a Hasan Ghorib hadith). The concept of forgiveness of self in this section related to spiritual concept. Spiritualty is defined as a deeply interpersonal relationship between person and a higher being 's that to release idea of religiosity, personal belief systems and faith practices (Elkins et al. 1988; Musgrace et al. 2002; Unantenne et al. 2013; Rafferty et al. 2014).

The concept of forgiveness of self also related to positive self-concept which means accepting shortcomings and strengths, so whatever negative things have happened to her/him, over time she/he can tolerate themself and let it slide. Who one's forgive of self also not regret what has happened, not complaining and not wishing for an event that had passed and had not taken place. It also means accepting all the events that had passed with an open heart. Respondents were more looking ahead than looking back. To forgive is to learn from past experience and to fix it in the future. Taking wisdom or lessons from bad past experiences means do not wanting to repeat the same mistakes, therefore he can learn from his past experience not to fall again for the same problem; stop interacting with the things that cause the problem (trigger), because it has a chance to repeat the same problem; be able to think logically and profoundly; only take wisdom from painful past events and then rise up to meet his future; regretting what has happened is something illogical such as time cannot be turned back and the past cannot be changed; patient and tolerant of everything that happens because they believed that after bad events there will be good and pleasant things for them.

Aceh conflict victims said that they are having hope for the future and optimistic. The person who has forgiven himself will be optimistic in achieving a better future. An optimistic person can get out 
of trouble easily. The self-forgiving person is convinced that God's Grace is vast, even though it is now in a bitter experience but never despair that one day he will meet the situation he aspires to. Last, Aceh conflict victims said that they are always be grateful. The person who has forgiven himself can be grateful for what his current state is. Especially when looking at others who are in worse conditions. The concept of forgiveness of self what explained by Tedeschi \& Calhoun (2004); Jayawickreme \& Blackie, (2014) that post-traumatic growth is the personality growth after an unwanted event which is a positive potential to release a past painful and future-oriented.

According to Aceh conflict victims, forgiveness of situations is has forgiven the situation believes that everything is God's destiny. Any endeavor cannot fight fate. The person who forgives the situation never regrets the situation of the incident, but is able to take lessons so that the same incident will not happen again, or if it happens again he already has ways to overcome it. The person who forgives the situation also has a desire to turn a painless situation into a pleasant situation when he sees no opportunity for it, for example, joining a community organization, a socio-political organization, publishing its experiences and thoughts about the painful situation and how to handle it, whether written or vocal. This definition more related with spirituality, post traumatic growth, coping strategy and hope.

While forgiveness of others defined as: First of all, forgiveness of others means people who able to accept others without the slightest feeling of vengeance. Aceh conflict victims said that is can be done if someone has a good relationship with God (Allah SWT). The person is convinced that there is happiness in the world and in the hereafter for someone who will forgive others. A Muslim does not need to be overwhelmed by stress and frustration because whatever he experiences is essentially all solutions already in the Qur'an.

Second, forgiveness of others means the ability to gain insight from a lesson is very important for a Acehnese as Muslim majority. Wisdom is a positive lesson from every occasion. Forgiveness is very closely connected with wisdom. The more wisdom obtained from an event the easier one forgives another person. Quran of Al Baqarah 269 surah says: "Allah bestows wisdom on whom He will. And whoever is blessed with wisdom, he has indeed been blessed with many gifts. And only those who believe can learn from it". Gain insight (the ability of lessons learned).

Third, forgiveness of others means not giving physical or psychological punishment. Forgiving others means not giving punishment of both physical and psychic punishment. But it does not matter if the authorities give the punishment.

Four, forgiveness of others means leave problems to the experts. People who forgive others do not mean they do not want to leave the issue to the authorities. The victim gives full authority to the authorities to pay off his case without requiring the authorities to impose penalties. Five, forgiveness of others means understand the mistakes of others. People who forgive others find ways to understand the mistakes of others.

Six, forgiveness of others means set aside the mistakes of others, just look at the advantages. People who forgive others try to put aside other people's mistakes, but that does not mean forgetting. The one who forgives others merely sees the strengths of others as a way of maintaining a relationship with that person. Seven, forgiveness of others means to be realistic, practice logical thinking, and 
INTERNATIONAL JOURNAL OF ACADEMIC RESEARCH IN BUSINESS AND SOCIAL SCIENCES Vol. 8, No. 8, August 2018, E-ISSN: 2222-6990 (C) 2018 HRMARS

focus on the purpose of lif. People who forgive others will think logically and deeply that thinking about the future is better than keeping the bitterness of the past, which certainly will not change what has happened.

Six, forgiveness of others means can pray for the good of the people who hurt us. People who forgive others also want to pray for the good of others. Seven, forgiveness of others means do not sacrifice others and do not forget that the person also has a family and friends who will be affected by what happened to him. Eight, forgiveness of others means do not throw out anger at others. Some forgiving people have displaced others by throwing out anger at those who hurt them by releasing angry emotions on others who are not at fault or inanimate objects, etc. For example, a mother who is angry at who kill her husband to throw out angry emotions on innocent children.

Nine, forgiveness of others means trigger has no power. In someone who has forgiven others, the trigger has no power to bring it back in the past. Ten, forgiveness of others means to be casual in meeting the person who hurt them. People who forgive others will treat others just as before a painful event occurs. Last, forgiveness of others means ready to attack when attacked in order to save them-selves.

Table 2. Dimensions of Forgiveness

\begin{tabular}{|c|c|c|}
\hline No & Types & Dimensions \\
\hline \multirow{11}{*}{1} & \multirow{11}{*}{$\begin{array}{l}\text { Forgiveness } \\
\text { of Self }\end{array}$} & Believe that everything is a scenario that God has established for one \\
\hline & & Having no regrets about what has happened \\
\hline & & Self-acceptance \\
\hline & & learn from past experiences to fix it in the future. \\
\hline & & Not repeat mistake \\
\hline & & Stop interacting with the things that cause the problem \\
\hline & & Be able to think logically and profoundly \\
\hline & & Patience \\
\hline & & Still have hope for future/Optimistic \\
\hline & & Not despair of God's grace \\
\hline & & Be grateful \\
\hline \multirow{3}{*}{2} & \multirow{3}{*}{$\begin{array}{l}\text { Forgiveness } \\
\text { of } \\
\text { Situations }\end{array}$} & Accept events as destiny from Allah \\
\hline & & Learn from the past \\
\hline & & Wish to change the situation \\
\hline \multirow{6}{*}{3} & \multirow{6}{*}{$\begin{array}{l}\text { Forgiveness } \\
\text { of Others }\end{array}$} & Hold no grudge \\
\hline & & Gain insight \\
\hline & & $\begin{array}{l}\text { Not giving physical or psychological punishment, but it does not } \\
\text { matter if the authorities give the punishment. }\end{array}$ \\
\hline & & $\begin{array}{l}\text { Leave problems to the experts. The victim gives full authority to the } \\
\text { authorities to pay off his case without requiring the authorities to } \\
\text { impose penalties, etc. }\end{array}$ \\
\hline & & Understand the mistakes of others \\
\hline & & Set aside the mistakes of others \\
\hline
\end{tabular}


INTERNATIONAL JOURNAL OF ACADEMIC RESEARCH IN BUSINESS AND SOCIAL SCIENCES Vol. 8, No. 8, August 2018, E-ISSN: 2222-6990 @ 2018 HRMARS

\begin{tabular}{|l|l|}
\hline \multirow{n}{|}{} & Realistic, practice logical thinking, and focus on the purpose of life \\
\hline & Pray for the good of the people who hurt them \\
\hline & Not sacrifice others. \\
\hline Do not throw out anger at others \\
\hline & $\begin{array}{l}\text { Trigger has no power to bring it back in the past. } \\
\text { Be casual in interact with the other person } \\
\text { Ready to attack when attacked in order to save them-selves }\end{array}$ \\
\hline
\end{tabular}

\section{Discussion}

The Aceh conflict victims concept of forgiveness influenced by socio-cultural norms of Aceh. The results reveal that for the Acehnese concept of forgiveness is closely related to the concept of positive psychology such spirituality, post traumatic growth (PTG), coping strategic and positive self-concept. Forgiveness of Aceh conflict victims meaning starts from self-will. Willingness is one of the emotion psychological aspect that found in the heart, while quality of heart is closely related to the quality of the relationship with God (spirituality.

Willingness may increase Aceh conflict victims ability to control thoughts, feelings and negative behavior about past bad experiences, so that it becomes positive thoughts, feelings and behaviors. One of those ability is called emotional intelligence. According to Golleman (2000) emotional intelligence is the ability to manage the emotional life with intelligence, maintaining the emotional appropriateness of emotion and its expression through self-awareness, self-control, self-motivation, empathy and social skills.

This study found that Aceh conflict victim's willingness to forgive their-self, situations, and others influenced by their spirituality, self-concept, coping strategy, and post traumatic growth. Amount study has been found the relationship between forgiveness and spirituality (Andrew et al. 2017)., forgiveness and post traumatic growth (Blackie et al, 2017), Watson \& Moris (2017), forgiveness and coping strategy (Hyun \& Bae, 2017, Weinberg, Gil, Gilbar, 2014), forgiveness and self-concept (Luchies et al. 2010). Accordingly, the meaning of forgiveness in this study is more focused on the effort of Aceh conflict victims to surrender their-selves to God by carrying out God's commands.

\section{Conclusion}

The Aceh conflict victims concept of forgiveness influenced by socio-cultural norms of Aceh. The results reveal that Aceh conflict victims concept of forgiveness is closely related to the concept of spirituality, post traumatic growth, coping strategy, self-concept, and emotional intelligence. The meaning of forgiveness of Aceh conflict victims is the willingness and ability to control negative thoughts, feelings and behaviours about bad experiences of the past into positive thoughts, feelings and behaviours whether it is forgiving oneself, situations or others. The customs and culture of Acehnese since the time of Aceh Darussalam Kingdom was shaped by Islamic religious values. In other words, the whole life of the Acehnese is influenced by Islamic values. After the earthquake and tsunami of Aceh December 26, 2004 awareness of Acehnese spirituality is very high. Most of the people of Aceh perceived the earthquake and tsunami as a warning from Allah Subhanallahutaala to stop bloodshed in Aceh. Spirituality is a major factor for Aceh conflict victims to be able to forgive themselves, to forgive the situation and to forgive others. Forgiveness is one's willingness to control the mind, feelings and behaviors that result in the ability to control the thoughts, feelings and behaviors for painful experiences in the past become neutral thoughts, feelings and behaviors. 
INTERNATIONAL JOURNAL OF ACADEMIC RESEARCH IN BUSINESS AND SOCIAL SCIENCES

Vol. 8, No. 8, August 2018, E-ISSN: 2222-6990 @ 2018 HRMARS

In line, many Aceh conflict victims used spirituality approach in solving their psychological problems that called spirituality of coping strategy such as remembrance, prayer, and surrender to Allah or tawakal in Arabic. Besides, this study also found that the positive self-concept in Aceh conflict victims has supported the manifestations of forgiveness. The positive self-concept of Acehnese is shaped by the awareness of Aceh's glorious historical experience, strong Islamic traditions, Aceh's culture and customs. Furthermore, Acehnese who are able to forgive themselves, to forgive the situation and to forgive others can grow well after the painful event or so-called post traumatic growth. Restoring all sides of Acehnese life to Islamic values is a must for achieving lasting peace in Aceh.

\section{Recommendations}

Forgiveness is one way to achieve lasting peace in Aceh. Having high spirituality is the way can be achieved forgiveness. Therefore, all parties, especially the decision-makers in Aceh, should give back the Acehnese the freedom to live according to their own culture and customs. The trick is to seek a high spirituality among Acehnese through the empowerment of all sides of Acehnese life (education, economy, health, law, socio-culture) based on strong Islamic values.

The Acehnese will react to fight if their culture and customs are disturbed. Therefore, if the peace agreement has been signed, the Acehnese, if they have forgiven and live in their habits and customs, then there should be no intervening parties, such as wanting to eliminate the Islamic Shari'a culture and local wisdom in Aceh. Strong base should be agreed to be a guideline in the implementation of maintaining peace in Aceh.

\section{Acknowledgment}

Researchers would like to thank to the Ministry of Research, Technology and Higher Education of Indonesia which has providing support of this study. A big thank you also goes to respondent of this study and also to Research and Community Service Institute of Malikussaleh University or LPPM UNIMAL.

\section{References}

Al-Qur'an dan terjemahannya. (2008). Departemen Agama RI . Bandung: Diponegoro.

Al Chaidar, D. (1998). Aceh bersimbah darah, mengungkap penerapan status DOM di Aceh 19891998. Jakarta: Pustaka Al Kautsar.

Alfian, T. I. (1999). Wajah Aceh dalam Lintasan Sejarah. Banda Aceh: Pusat Dokumentasi dan Informasi Aceh.

Alfian, T, I., Basry, M. H., Ismail, S., Sahar, L. (1997). Perang Kolonial Belanda di Aceh. Banda Aceh: Pusat Dokumentasi dan Informasi Aceh.

Aalgaard, R. A., Bolen, R. M., \& A, W. R. N. (2016). A literature review of forgiveness as a beneficial intervention to increase relationship satisfaction in couples therapy, 1359 (January). http://doi.org/10.1080/10911359.2015.1059166 
INTERNATIONAL JOURNAL OF ACADEMIC RESEARCH IN BUSINESS AND SOCIAL SCIENCES Vol. 8, No. 8, August 2018, E-ISSN: 2222-6990 @ 2018 HRMARS

Andrews, B., Watson, P. J., Chen, Z. J., \& Morris, R. J. (2017). Postmodernism, positive psychology and post-traumatic growth within a Christian ideological surround. Journal of Positive Psychology, 12(5), 489-500.

Berg, M., \& Dahlberg, K. (2001). Swedish midwives' care of women who are at high obstetric risk or who have obstetric complications. Midwifery, 17(4), 259-66. https://doi.org/10.1054/midw.2001.0284

Blackie, L. E. R., Jayawickreme, E., Tsukayama, E., Forgeard, M. J. C., Roepke, A. M., \& Fleeson, W. (2017). Post-traumatic growth as positive personality change: Developing a measure to assess within-person variability. Journal of Research in Personality, 69, 22-32. https://doi.org/10.1016/j.jrp.2016.04.001

Blackie, L. E. R., \& Jayawickreme, E. (2014). Promoting change in post-traumatic growth research: Response to commentaries. European Journal of Personality, 28, 351-361. http://dx.doi.org/10.1002/per.1970.

Bochner, S. (1994). Cross-cultural differences in the self-concept. Journal of Cross-Cultural Psychology, 25, 273-283.

Carlson, N. R., Psychology, the Science of Behavior, sixth edition, (United States of America, Pearson Education Inc, 2007), p. 536.

Community Care of Humanity. 2011. Community-based psychosocial and mental health services in North Aceh. Project-support by SERASI-USAID.

Enright RD (2001) Forgiveness is a choice. APA Books, Washington, DC.

Enright, R.D; North, J. (1998). Exploring Forgiveness. US: University of Wisconsin Press.

Enright, R. D., \& Fitzgibbons, R. P. (2000). Helping clients forgive: An empirical guide for resolving anger and restoring hope. Washington, DC: American Psychological Association.

Enright RD, Fitzgibbons R (2015) Forgiveness therapy. APA Books, Washington DC.

Fincham, F. D. (2015). Forgiveness, Family Relationships and Health. http://doi.org/10.1007/978-94$\underline{017-9993-5}$

Hartini, N. (2011). Remaja Nanggroe Aceh Darussalam Paska Tsunami. Departemen Psikologi Klinis dan Kesehatan Fakultas Psikologi Universitas Airlangga. 24 (1). 45-51

Hurlock, E.B. 1973. Adolescent Development. Japan: Kosaldo Printing Co. LTD.

Sawitri, I, Zamzami, A, Wihoho, B. (1999). Simak dan Selamatkan Aceh. PT. Bina Rena Pariwara.

T.Syamddin, dkk. Adat istiadat Propinsi D.I. Aceh. Jakarta: Depdikbud Proyek Penelitian dan Pencatatan Kebudayaan Daerah.

Muhammad Umar, M. 2002. Darah dan Jiwa Aceh Mengungkap Falsafah Hidup Masyarakat Aceh. Banda Aceh: Yayasan Busafat

Hyun, M., \& Bae, S. (2017). The in fl uences of cognitive appraisal, physical injury, coping strategy, and forgiveness of others on PTSD symptoms in traf fi c accidents using hierarchical linear modeling. Medicine, 96(35).

Khanjani, M. S., Younesi, S. J., Khankeh, H. R., \& Azkhosh, M. (2017). Exploring Facilitators of Posttraumatic Growth in Patients with Spinal Cord Injury: A Qualitative Study. Electronic Physician, 9(1), 3544-3553. https://doi.org/10.19082/3544. 
INTERNATIONAL JOURNAL OF ACADEMIC RESEARCH IN BUSINESS AND SOCIAL SCIENCES

Vol. 8, No. 8, August 2018, E-ISSN: 2222-6990 @ 2018 HRMARS

Luchies, L. B., Finkel, E. J., McNulty, J. K., \& Kumashiro, M. (2010). The doormat effect: When forgiving erodes self-respect and self-concept clarity. Journal of Personality and Social Psychology, 98(5), 734-749. https://doi.org/10.1037/a0017838

Leeuwen, A. J. J. M. V. R. Van. (2017). The Role of Spirituality in Lifestyle Changing Among Patients with Chronic Cardiovascular Diseases: A Literature Review of Qualitative Studies. Journal of Religion and Health. https://doi.org/10.1007/s10943-017-0384-2

Lutjen, L. J., Silton, N. R., \& Flannelly, K. J. (2012). Religion, Forgiveness, Hostility and Health: A Structural Equation Analysis, 468-478. . http://doi.org/10.1007/s10943-011-9511-7

Maltby, J., Day, L., \& Barber, L. (2004). Forgiveness and mental health variables: Interpreting the relationship using an adaptational-continuum model of personality and coping, 37, 16291641. http://doi.org/10.1016/j.paid.2004.02.017

Matter, N., Mcfarland, M. J., Smith, C. A., Toussaint, L., \& Thomas, P. A. (2012). Forgiveness of Others and Health : Do Race and, 67, 66-75. . http://doi.org/10.1093/geronb/gbr121.

North J (1987) Wrong doing and forgiveness. Philosophy 62: 499-508.

Nurrachman, N. (2005). Psikologi Paska Trauma: Perspektif Sosial Klinis dan Lintas Budaya. Psikologi Paska Trauma, 1(1).

Svalina, S. S., \& Webb, J. R. (2012). Forgiveness and health among people in outpatient physical therapy, 34(July 2011), 383-392. . http://doi.org/10.3109/09638288.2011.607216

Tedeschi, R. G., \& Calhoun, L. G. (2004). Posttraumatic growth: Conceptual foundations and empirical evidence. Psychological Inquiry, 15, 1-18. http://dx. doi.org/10.1207/s15327965pli1501_01.

Warmke, B., \& Warmke, B. (2016). The Normative Significance of Forgiveness The Normative Signi fi cance of Forgiveness, 8402 (June). e). http://doi.org/10.1080/00048402.2015.1126850

Webb, J. R., Phillips, T. D., Bumgarner, D., \& Conway-williams, E. (2012). Forgiveness, Mindfulness, and Health. http://doi.org/10.1007/s12671-012-0119-0

Weinberg, M., Gil, S., \& Gilbar, O. (2014). Forgiveness, coping, and terrorism: Do tendency to forgive and coping strategies associate with the level of posttraumatic symptoms of injured victims of terror attacks? Journal of Clinical Psychology, 70(7), 693-703. https://doi.org/10.1002/jclp.22056 